Available online at GSC Online Press Directory

GSC Biological and Pharmaceutical Sciences

e-ISSN: 2581-3250, CODEN (USA): GBPSC2

Journal homepage: https://www.gsconlinepress.com/journals/gscbps

(RESEARCH ARTICLE)

\title{
Study on in vitro antioxidant activities of Chrysophyllum albidum G. Don stem-bark
}

\author{
Akanji Olufunke Christy* \\ Department of Plant Science and Biotechnology, Faculty of Science, Adekunle Ajasin University PMB 001, Akungba \\ Akoko.Ondo State, Nigeria.
}

Publication history: Received on 20 December 2019; revised on 03 April 2020; accepted on 06 April 2020

Article DOI: https://doi.org/10.30574/gscbps.2020.11.1.0248

\begin{abstract}
Chrysophyllum albidum G.Don is commonly known as African star apple. It possesses medicinal properties and used in folk medicine for the treatment of coronary heart diseases, stroke, anti-inflammatory, diabetes, cancers and diarrhea. Natural antioxidants either in the form of raw extracts or their chemical constituents are very effective to prevent the destructive processes caused by oxidative stress. The present study was carried out to investigate the phytochemicals and antioxidant activities of ethanol extract of Chrysophyllum albidum stem-bark. The phytochemical tests reviewed the presence of alkaloids (53\%), tannins (6\%), saponins (21\%), flavonoids (10.25\%), cardiac glycosides (21.36\%), steroids (7.58\%) and anthraquinone (8.72\%). The overall antioxidant activities observed in the stem-bark of Chrysophyllum albidum showed strong free radical scavenging activity with DPPH $(81.88 \pm 0.83$ at $50 \mathrm{mg} / \mathrm{ml})$ when compared with the reference chemical (TROLOX). The present study validates the traditional use, demonstrating that the stem-bark of Chrysophyllum albidum possesses concentration-dependent antioxidant activity.
\end{abstract}

Keywords: Chrysophyllum albidum; Folk medicine; Antioxidant; DPPH.

\section{Introduction}

An antioxidant is a molecule capable of showing or preventing the oxidation of other molecules.Oxidation is a chemical reaction that tranfers electrons from a substance to an oxidizing agent. Oxidation reactions can produce free radicals, which start chain reactions that damage cells. Antioxidants terminate these chain reactions by removing free radical intermediates, and inhibit other oxidation reactions by oxidizing it. Therefore, the main characteristic of an antioxidant is its ability to trap or scavenge free radicals generated as part of body's normal metabolic processes, thus inhibiting the oxidative mechanisms that lead to degenerative diseases or pathological disorder such as ischemia, cancer, gastrointestinal inflammation, asthma, cataracts, cardiovascular disease, diabetes mellitus, aging process, neurological degeneration and other inflammatory processes [1]. Antioxidant-based drugs/formulations for the prevention and treatment of these diseases have appeared during the last 3 decades [2]. This has attracted a great deal of research interest in natural antioxidants. Subsequently, a worldwide trend towards the use of natural phytochemicals present in berry crops, tea, herbs, oilseeds, beans, fruits, and vegetables has increased $[3,4,5]$. Several herbs and spices have been reported to exhibit antioxidant activity, including rosemary, sage, thyme, nutmeg, turmeric, white pepper, chili pepper, ginger, and several medicinal plant extracts $[6,7]$.

Chrysophyllum albidum, commonly known as Africa star apple, is a wildly grown plant which belongs to the family of trees known as Sapotaceae which has about 800 species [8. 9]. It is a common plant among many locals in Nigeria (particularly in Ondo State) where the fleshy pulp of the fruit is eaten chiefly as snack and its fruit has been found to have the highest content of ascorbic acid with 1000 to 3,330 mg of ascorbic acid per $100 \mathrm{~g}$ of edible fruit or about 100 times that of oranges and 10 times of that of guava or cashew [1,3]. It is also reported as an excellent source of vitamins, irons, and flavors to diets. Preceding studies in Western Africa have shown that the roots, barks and leaves of

\footnotetext{
${ }^{*}$ Corresponding author: Olufunke Christy Akanji
} 
Chrysophyllum albidum have been employed in folk medicine for the treatment of various diseases such as skin eruption, stomach ache, diarrhea, yellow fever, malaria [11, 12], heart diseases, stroke, diabetes and cancers [2]. In spite of the rich component and vast local use of Chrysophyllum albidum stem-bark, there is dearth of information on its' antioxidant properties. Thus, the present study was aimed to investigate the in vitro antioxidant activity of ethanol extract of Chrysophyllum albidum stem-bark.

\section{Material and methods}

\subsection{Plant material and extraction}

Plant specimen (stem-bark) was collected locally or obtained from Apex Academy premises, Ibaka Akungba Akoko, Ondo State. Nigeria. The plant was identified and authenticated at Forest Research Institute of Nigeria (FRIN) Ibadan, Oyo State. The voucher specimen was deposited in Forest Herbarium, Ibadan (FHI) at FRIN as 110130 and also deposited at the Department of Plant Science and Biotechnology Herbarium, Adekunle Ajasin University, Akungba akoko, Ondo State. Nigeria. About $400 \mathrm{~g}$ of dried, powdered plant material was macerated in ethanol for 7 days. The final extract was passed through No.1 Whatman filter paper (Whatman Ltd., England). The filtrate obtained was concentrated under vacuum on a rotary evaporator at $40^{\circ} \mathrm{C}$ and stored at $4{ }^{\circ} \mathrm{C}$ for further use.

\subsection{Quantitative and qualitative phytochemical analyses}

The screenings of the sample were carried out for the determination of alkaloid, saponins, tannins, anthraquinones, cardiac glycoside, flavonoids and steroids $[13,14]$.

\section{In vitro studies}

\subsection{DPPH scavenging activity}

The free radical scavenging ability of the extract was determined by DPPH (1,1-diphenyl-2-picryhydrazyl) [15]. 1 ml of the extract or standard (Trolox) was mixed with $1 \mathrm{ml}$ of the $0.4 \mathrm{mM}$ methanol solution of the DPPH. The mixture was left in the dark for $30 \mathrm{~min}$ before measuring the absorbance at $516 \mathrm{~nm}$ and the scavenging ability of the extract was calculated as:

DPPH radical scavenging activity $(\%)=[($ Abs control - Abs sample $)]$

(Abs control)

Where Abs control is the absorbance of DPPH radical + methanol; Abs sample is the absorbance.

\subsection{Estimation of total phenolic content}

The total phenolic content of the extract was estimated by mixing $0.2 \mathrm{ml}$ of the extract thoroughly with $2.5 \mathrm{ml}$ of $10 \%$ Folin ciocalteau's reagent and $2 \mathrm{ml}$ of $7.5 \%$ Sodium carbonate. The reaction mixture was subsequently incubated at $45^{\circ} \mathrm{C}$ for $40 \mathrm{mins}$, and the absorbance was measured at $700 \mathrm{~nm}$ in the spectrophotometer. Garlic acid was used as standard phenol.

\subsection{Estimation of total flavonoids}

The total flavonoid content of the extract was determined using a colorimeter assay developed by [16]. 0.2ml of the extract was added to $0.3 \mathrm{ml}$ of $5 \% \mathrm{NaNO}_{3}$ at zero time. After 5 minutes, $0.6 \mathrm{ml}$ of $10 \% \mathrm{AlCl}_{3}$ was added and after 6 minutes, $2 \mathrm{ml}$ of $1 \mathrm{M} \mathrm{NaOH}$ was added to the mixture followed by the addition of $2.1 \mathrm{ml}$ of distilled water. Absorbance was read at $510 \mathrm{~nm}$ against the reagent blank and flavonoid content was expressed as mg rutin equivalent.

\subsection{ABTS scavenging activity}

The ABTS (2,2-azino-bis(3-ethylbenthiazoline-6-sulphonic acid) scavenging ability of the extract was determined by [17]. The ABTS was generated by reacting $7 \mathrm{mM}$ ABTS aqueous solution with $\mathrm{K}_{2} \mathrm{~S}_{2} \mathrm{O}_{8}$ (2.45 mM/l, final conc.) in the dark for 16 hours and adjusting the absorbance at $734 \mathrm{~nm}$ to 0.700 with ethanol. $0.2 \mathrm{ml}$ of the appropriate dilution of the extract was then added to $2.0 \mathrm{ml}$ of ABTS solution and the absorbance was read at $732 \mathrm{~nm}$ after 15 minutes. The TROLOX (6-hydroxyl-2,5,7,8-tetramethyl chroman-2-carboxylic acid) equivalent antioxidant capacity was subsequently calculated. 


\subsection{Superoxide (S0) anion scavenging activity assay}

The superoxide anion radicals were produced in $2 \mathrm{ml}$ of phosphate buffer $(100 \mathrm{mM}, \mathrm{pH} 7.4)$ with $78 \mu \mathrm{M} \beta$ - nicotinamide adenine dinucleotide (NADH), $50 \mu \mathrm{M}$ nitro blue tetrazoliumchloride (NBT) and test samples at different concentrations. The reaction mixture was kept for incubation at room temperature for $5 \mathrm{~min}$. It was then added with 5methylphenazinium methosulphate (PMS) $(10 \mu \mathrm{M})$ to initiate the reaction and incubated for $5 \mathrm{~min}$ at room temperature. The colour reaction between superoxide anion radical and NBT was read at $560 \mathrm{~nm}$. Vitamin C was used as a positive control agent for comparative analysis. The reaction mixture without test sample was used as control and without PMS $\left(\mathrm{C}_{4} \mathrm{H}_{12} \mathrm{~N}_{2} \mathrm{SO}_{4}\right)$ was used as blank [18]. The percentage inhibition of superoxide anion radical was calculated as:

Superoxide anion radical scavenging activity $(\%)=[($ Abs control- Abs sample $)] \times 100$

(Abs control)

Where Abs control is the absorbance of superoxide anion radicals, Abs sample is the absorbance of superoxide anion radical + plant extract.

\subsection{Hydroxyl $(\mathrm{OH})$ Radical Scavenging Activity}

The ability of the extract to prevent $\mathrm{Fe}^{2+} / \mathrm{H}_{2} \mathrm{O}_{2}$ induced decomposition of deoxyribose was carried out using modified method [19]. The extract $(100 \mu \mathrm{l})$ was added to a reaction mixture containing $120 \mu \mathrm{l}, 20 \mathrm{mM}$ deoxyribose, $400 \mu \mathrm{l}, 0.1 \mathrm{M}$ phosphate buffer $\mathrm{pH} 7.4,40 \mu \mathrm{l}, 20 \mathrm{mM}$ hydrogen peroxide and $40 \mu \mathrm{l}, 500 \mu \mathrm{M} \mathrm{FeSO}$, and the volume was made to $800 \mu \mathrm{l}$ with distilled water. The reaction mixture was incubated at $37^{\circ} \mathrm{C}$ for $30 \mathrm{~min}$ and the reaction was stopped by the addition of $0.5 \mathrm{ml}$ of $2.8 \% \mathrm{TCA}$, this was followed by the addition of $0.4 \mathrm{ml}$ of $0.6 \%$ TBA solution. The reaction mixture was subsequently incubated in boiling water for $20 \mathrm{~min}$. The absorbance was measured at $532 \mathrm{~nm}$ in spectrophotometer.

$$
\% \text { inhibition }=\left[\left(\mathrm{A}_{0}-\mathrm{A}_{1}\right)\right] \times 100
$$

\section{$\left[\mathrm{A}_{0}\right]$}

Where $A_{o}$ is the absorbance of the control, $A_{1}$ is the absorbance in the presence of plant extract and known standard.

\subsection{Statistical analysis}

Each test was performed in duplicate and the results were expressed as mean \pm standard deviation. The results were statistically assessed by one-way analysis of variance (ANOVA). $\mathrm{P}<0.05$ was considered significant. One way ANOVA diagnosis of the data was done using SPSS software.

\section{Results and discussion}

Percentage yield of the ethanol extract of powdered stem-bark of Chrysophyllum albidum was $26.09 \%$, the yield was low when compared to results of extract yield from plant sources of other authors [20,21]. Basically, extraction of bioactive components from medicinal plant is known to permit the demonstration of their physiological activity as well as to facilitate pharmacological studies on the plant leading to synthesis and discovery of pure and potent compounds that have low toxicity when used as drugs. The results of phytochemical screening showed presence of Alkaloids, Tannins, Steroids, Flavonoids, Saponins, Cardiac glycosides and Anthraquinone in the ethanol extract of C. albidum stem-bark screened for secondary metabolites (Table 1). These secondary metabolites were known to show medicinal activities as well as exhibiting physiological activities [22]. The quantitative analysis results (Table 2) showed that Alkaloids had the highest percentage (53.00\%) while Tannins had the least percentage (6.33\%). Alkaloids often have pharmacological effects and are used as medications and recreational drugs such as antimalarial agents, analgesics and can act as stimulants. Glycoside moieties such as saponins, anthraquinones, cardiac glycosides and flavonoids can inhibit tumor growth, act as an antiparasitic agent, and can be used as an antidepressant. The antioxidant activity of the ethanol extract of Chrysophyllum albidum stem-bark was investigated against in vitro models. Since, free radicals are of different chemical entities, it is essential to test the extract against many free radicals to prove its antioxidant activity. Hence, a large number of in vitro methods were used for the screening. Free radicals are known to play a definite role in a wide variety of pathological manifestations. Antioxidants fight against free radicals and protect us from various diseases. They exert their action either by scavenging the reactive oxygen species or protecting the antioxidant defense mechanisms [23]. Herbal drugs containing free radical scavengers are gaining importance in treating diseases. The antioxidant activities of ethanol extract of $C$. albidum stem-bark were evaluated by DPPH radical scavenging activity, Hydroxyl radical scavenging activity $(\mathrm{OH})$, Total phenolic content, Total flavonoids, ABTS scavenging activity and 
Superoxide (SO) radical scavenging activity. The anti-radical and antioxidant activities of the extract using different methods showed that these activities vary, depending on their concentrations. The $\mathrm{IC}_{50,100,200} \& 300$ of the extract on Phenol, Flavonoid, OH, ABTS, DPPH and SO varied from 8.30 to $31.14 \mathrm{mg} / \mathrm{ml}, 8.30$ to $27.40 \mathrm{mg} / \mathrm{ml}, 17.76$ to $40.48 \mathrm{mg} / \mathrm{ml}$, 21.47 to $46.46 \mathrm{mg} / \mathrm{ml}$ and 62.54 to $84.14 \mathrm{mg} / \mathrm{ml}$ respectively (Table 3 ). The noticeable increase in the antioxidant properties of this plant could serve as a significant indicator of its antioxidant potential when compared with the reference chemicals (Table 4). The result showed that DPPH had the highest activity when compared with all other parameters investigated The DPPH is a stable free radical, which has been widely accepted as a tool for estimating free radical scavenging activities of antioxidants. A high proportion of antioxidants in our diet prevent the body from any oxidative damage in order to maintain a better healthy condition and also to slow down aging process. Numerous studies have shown that antioxidants have protective effects on health problems. It was reported that antioxidant prevents the occurrence of diseases, like cancer, aging and that they can also interfere with the oxidation process by reacting with free radicals, chelating, catalytic metals and also by acting as oxygen scavenger [24].

Table 1 Preliminary qualitative phytochemical result of C. albidum stem-bark

\begin{tabular}{|c|c|c|}
\hline TEST & OBSERVATION & INFERENCE \\
\hline \multicolumn{3}{|l|}{ Alkaloids } \\
\hline Dragendorff's reagent & Yellow precipitate. & ++ \\
\hline Mayer's test & Dark yellowish precipitate. & ++ \\
\hline \multicolumn{3}{|l|}{ Saponins } \\
\hline Frothing test & Frothing persist. & ++ \\
\hline Benedict test & Blue-Black precipitate. & ++ \\
\hline \multicolumn{3}{|l|}{ Tannins } \\
\hline $2 \mathrm{ml}$ of extract $+2 \mathrm{ml} \mathrm{Fecl}_{3}$ & Brownish-Green. & +++ \\
\hline $2 \mathrm{ml}$ of extract $+2 \mathrm{ml}$ bromine. & Blue-Black precipitate. & +++ \\
\hline \multicolumn{3}{|l|}{ Flavonoids } \\
\hline $2 \mathrm{ml}$ of extract $+2 \mathrm{ml}$ of $10 \%$ Lead & Yellowish precipitate. & ++ \\
\hline acetate. & Golden precipitate. & ++ \\
\hline \multicolumn{3}{|l|}{$2 \mathrm{ml}$ of extract $+2 \mathrm{ml}$ dil. $\mathrm{NaOH}$} \\
\hline \multicolumn{3}{|l|}{ Cardiac Glycoside } \\
\hline Keller-Kiliani test & Brownish ring. & ++ \\
\hline Kedde test & Reddish-Brown ring. & ++ \\
\hline \multicolumn{3}{|l|}{ Steroids } \\
\hline $\begin{array}{l}2 \mathrm{ml} \text { of extract }+4 \mathrm{ml} \text { of acetate } \\
\text { anhydride }+2 \mathrm{ml} \mathrm{of} \mathrm{H}_{2} \mathrm{SO}_{4}\end{array}$ & Violet coloration. & + \\
\hline \multicolumn{3}{|l|}{ Anthraquinone } \\
\hline Borntrager's test & Violet coloration & ++ \\
\hline
\end{tabular}

KEY NOTE: +++ HIGHLY POSITIVE, ++ MODERATETY POSITIVE, + POSITIVE 
Table 2 Results of quantitative analysis of C. albidum

\begin{tabular}{|c|c|c|}
\hline S/N & Phytochemicals & Mean \pm standard deviation \\
\hline & Alkaloid & $53.00 \pm 0.5$ \\
\hline & Saponin & $21.18 \pm 0.64$ \\
\hline & Tannin & $6.33 \pm 0.38$ \\
\hline & Flavonoid & $10.25 \pm 0.01$ \\
\hline & Cardiac glycoside & $21.36 \pm 0.20$ \\
\hline & Steroids & $7.58 \pm 0.04$ \\
\hline & Anthraquinone & $8.72 \pm 0.08$ \\
\hline
\end{tabular}

Table 3 Results of the antioxidant properties of C. albidum stem-bark

\begin{tabular}{lllll}
\hline Concentrations $(\mathbf{m g} / \mathbf{m l})$ & $\mathbf{5 0}$ & $\mathbf{1 0 0}$ & $\mathbf{2 0 0}$ & $\mathbf{3 0 0}$ \\
\hline Phenol & $8.30 \pm 0.15$ & $11.66 \pm 0.15$ & $21.41 \pm 0.01$ & $31.14 \pm 0.15$ \\
Flavonoid & $8.3 \pm 0.02$ & $6.62 \pm 0.03$ & $17.13 \pm 0.02$ & $27.40 \pm 0.31$ \\
OH & $17.76 \pm 0.58$ & $20.03 \pm 0.58$ & $30.54 \pm 0.59$ & $40.48 \pm 0.15$ \\
DPPH & $81.88 \pm 0.83$ & $84.66 \pm 0.35$ & $95.66 \pm 0.35$ & $98.60 \pm 0.36$ \\
ABTS & $21.47 \pm 0.05$ & $24.49 \pm 0.65$ & $35.45 \pm 0.05$ & $46.46 \pm 0.65$ \\
SO & $62.54 \pm 0.48$ & $64.17 \pm 0.22$ & $74.51 \pm 0.48$ & $84.14 \pm 0.48$ \\
\hline
\end{tabular}

Values are represented as mean \pm standard deviation.

Table 4 Reference chemicals against antioxidant parameters

\begin{tabular}{|c|c|c|c|c|}
\hline Reference chemical & Galic & Rutin & Vitamin C & Trolox \\
\hline Phenol & $0.07 \pm 0.02$ & & & \\
\hline Flavonoid & & $0.05 \pm 0.12$ & & \\
\hline $\mathrm{OH}$ & & & $0.09 \pm 0.45$ & \\
\hline DPPH & & & & $0.09 \pm 0.23$ \\
\hline ABTS & & & & $0.09 \pm 1.03$ \\
\hline so & & & $0.09 \pm 0.24$ & \\
\hline
\end{tabular}

\section{Conclusion}

This study showed that the stem-bark of $C$. albidum had significant number of useful bioactive components and also a lot of potentials as an antioxidant agent. These observed activities provided the basis for their folkloric uses, as cure for some human ailments like skin infection, diarrhea and stomach-ache, which are as a result of infections and inflammatory reaction. The results of this study justified the traditional uses of the stem-bark of $C$. albidum for therapeutic purposes. 


\section{Compliance with ethical standards}

\section{Acknowledgments}

The author appreciates the technologists in the Departments of Plant Science and Biotechnology, and Chemical Sciences, AAUA, for their technicalities and supports. Thank you.

\section{Disclosure of conflict of interest}

The author declared no conflict of interest.

\section{References}

[1] Idowu TO, Iwalewa EO, Aderogba MA, Akinpeluy BA and Ogunduini AO. (2006). Alkaloid Isolated from Chrysophyllum albidum Seed Cotyledons, Journal of Biological Sciences, 6(6), 1029-1034.

[2] Devasagayam TPA, Tilak JC, Boloor KK, Sane KS, Ghaskadbi SS and Lele RD. (2004). Review: Free radicals and antioxidants in human health: Current Status and Full Prospects. J. Assoc Physicians India, 52, 794-804.

[3] Deiana M, Arouma OI and Bianchi M. (1999). Inhibition of peroxinitite dependent DNA base modification and tyrocin nitration by the extra virgin olive oil derived antioxidant hydroxytyrosol. Free Radical Biology and Medicine, 26, 762-769.

[4] Lee KG and Shibamoto T. (2000). Antioxidant properties of the Aroma compounds isolated from soyabean and mung beans. Journal of Agriculture and Food Chemistry, 48, 4290-4293.

[5] Wang Z, Huang Y, Zou J, Cao K, Xu Y and Wu JM. (2002). Effects of red wine and wine polyphenol resveratrol on platelet aggregation in vivo and in vitro: International Journal of Molecular Medicine, 9(1), 77-79.

[6] Kikuzaki H, Usuguchi J and Nakatani N. (1991). Constituents of Zingiberaceae I. Diarylheptanoid from the rhizomes of ginger (Zingiber officinale Roscoe). Chemistry and Pharmacy Bull, 39, 120.

[7] Jitoe A, Masuda T and Tengah IGP. (1992). Antioxidant activity of tropical ginger extracts and analysis of the contained curcuminoids. Journal of Agricultural and Food Chemistry, 8, 1337.

[8] Ethiagbonare, JE, Onyibe HI and Okoegwale EE. (2008). Studies on the isolation of normal and abnormal seedlings of Chrysophyllum albidum: A step towards sustainable management of the taxon in the 21st century: Science Research Essay, 3(12), 567-570.

[9] Duyilemi OP and Lawal IO. (2009). Antibacterial activity and phytochemical screening of Chrysophyllum albidum Leaves: Asian Journal of Food and Agro-Industry. Special Issue, S75-79.

[10] Amusa NA, Ashaye OA and Oladapo MO. (2003). Biodeterioration of the African star apple (Chrysophyllum albidum) in storage and the effect on its food value: African Journal of Biotechnology, 2(3), 56-59.

[11] Adewusi HA. (1997). The African Star Apple Chrysophyllum albidum Indigenous Knowledge from Ibadan, Southwestern Nigeria: In Proceedings of a National Workshop on the Potentials of the Star Apple in Nigeria (Eds.), $25-33$.

[12] Bada SO. (1997). Preliminary information on the ecology of Chrysophyllum albidum done in the West and Central Africa: In proceedings of a National Workshop on the potentials of Star Apple in Nigeria, 16 - 25.

[13] Marker AOS and Goodchild AV. (1996). Qualification of Tannis. A laboratory Manual International Centre of Agricultural Research in Dry Areas (ICRDA). Alleppo Syria, 4, 25.

[14] Sofowora A. (2008). Medicinal Plants and Traditional Medicine in Africa'. 3rd edn. Spectrum Books, Ibadan, 64 79.

[15] Gyamfi MA, Yonamine M. and Aaniya Y. (1999). Free radical scavenging action of medicinal herbs from Ghana: thonningia sanguine on experimentally induced liver injuries. General Pharmacology, 32, 661 - 667.

[16] Bao JY, Cai M, Sun G, Wang M and Corke H. (2005). Anthocyanins, Flavonoid and Free Radical Scavenging Activity of thines Baybery (Myrialrubia) extracts and their colour properties and stability. Journal of Agriculture and Food Chemistry, 53, 2327 - 2332. 
[17] Re R, Pellegrin N, Proteggente A, Pannala A, Yang M and Rice-Evans C. (1999). Antioxidant activity applying an improve ABTS Radical cation decolourization assay. Free Radical Biology and Medicine, 26, 1231-1237.

[18] Selvakumar K, Madhan R, Srinivasan G and Baskar V. (2011). Antioxidant Assays in Pharmacological Research. Asian Journal of Pharmaceutical Technology, 1(4), 99-103.

[19] Halliwell B and Gutteridge JM. (1999). Formation of a thiobarbituric-acid-reactive substance from deoxyribose in the presence of iron salts: The role of superoxide and hydroxyl radicals FEBS. Letter, 128, 347-352.

[20] Owolabi OJ, Omogbai E and Obasuyi O. (2007). Antifungal and antibacterial activities of the ethanolic and aqueous extracts of Kigelia africana (Bignoniaceae) stem bark. African Journal of Biotechnology, 6(14), 1677-1680.

[21] Doughari JH, El-Mahmood AM and Tyoyina I. (2008). Antibacterial activity of leaf extracts of Senna obtusifolia. African Journal of Pharmaceutical Pharmacology, 2(1), 007-013.

[22] Sofowora A. (1993). Medicinal Plants and Traditional Medicine in Africa 2nd Edn. Spectrum Books Limited, Ibadan, Nigeria, 14-34.

[23] Umamaheswari M and Chatterjee TK. (2008). In vitro antioxidant activities of the fractions of Coccinnia grandis L. leaf extract. African Journal of Traditional Complementary and Alternative Medicine, 5, 61-73.

[24] Kumpulainen JT and Salonen JT. (1999). Natural Antioxidants and Anticarcinogens in Nutrition, Health and Disease: The Royal Society of Chemistry, UK. 178- 187.

\section{How to cite this article}

Akanji OC. (2020). Study on in vitro antioxidant activities of Chrysophyllum albidum G. Don stem-bark. GSC Biological and Pharmaceutical Sciences, 11(1), 78-84. 